Journal of

International Logistics and Trade

\title{
The Development of River-based Intermodal Transport: The Case of Ukraine
}

\author{
Grushevska K., ${ }^{\mathrm{a}, *}$, Notteboom T. ${ }^{\mathrm{a}, \mathrm{b}, \mathrm{c}, \mathrm{d}}$ \\ ${ }^{a}$ Faculty of Applied Economics, University of Antwerp, Antwerp, Belgium \\ ${ }^{\mathrm{b}}$ China Institute of FTZ Supply Chain, Shanghai Maritime University, Shanghai, China \\ ${ }^{c}$ Maritime Institute, Faculty of Law, Ghent University, Ghent, Belgium \\ ${ }^{\mathrm{d}}$ Antwerp Maritime Academy, Antwerp, Belgium
}

\begin{tabular}{|c|c|}
\hline ARTICLE INFO & ABSTRACT \\
\hline $\begin{array}{l}\text { Article history: } \\
\text { Received } 3 \text { June } 2016 \\
\text { Accepted } 22 \text { November } 2016 \\
\text { Keywords: } \\
\text { Regionalization } \\
\text { Gateway ports } \\
\text { Ukraine } \\
\text { Intermodality } \\
\text { Inland waterways }\end{array}$ & $\begin{array}{l}\text { It should be noted that the (inland waterway transport) IWT in Ukraine currently is in its } \\
\text { infancy in comparison with other land based transport means (rail and road) and with other } \\
\text { countries that possess navigable rivers. This paper is an extension of the research initiated by } \\
\text { Grushevska and Notteboom (2015) where the concepts of intermediacy and centrality were } \\
\text { introduced in order to assess the role of Ukraine in the global and regional transport networks. } \\
\text { The list of key obstacles for Ukraine's intermediacy function included IWT related barriers } \\
\text { such as: (i) deficient inland waterway infrastructure, (ii) high IWT costs (fees for bridges, } \\
\text { locks etc.) and (iii) pilotage charges. To date the transportation to/from ports is mainly } \\
\text { fulfilled by road or by rail based multimodal transport solutions. We present the unutilized } \\
\text { potential of Ukrainian IWT that needs to be efficiently exploited for the benefit of the national } \\
\text { economy and national transport system. This study intends to enrich the limited academic } \\
\text { research on IWT systems in a transition stage, as exemplified by the case of Ukraine. }\end{array}$ \\
\hline
\end{tabular}

\section{Introduction}

Since its independence in 1991, Ukraine has been subject to many lost opportunities and let-downs, economic mismanagement and hesitant reforms holding back growth, corruption and oligarchy undermining the market economy, and episodes of power undercutting democracy. Ukraine's per capita income at independence was higher than Poland's. Twenty years later in 2013, even before the current crisis erupted, the standard of living had fallen more than 60 percent behind Poland. During the period between 2009 and 2014, Ukraine entered into eight IMF programs, none of which achieved the objective of inducing sustained reform. For several years, wages and costs rose, but productivity did not. Eventually competitiveness had slipped so much that GDP stopped rising and exports stagnated. Budget imbalances and gas sector deficits widened enough to add another drag on growth.

Despite the rugged current economic and political situation in Ukraine, the new government is strongly motivated and active in implementing long-awaited reforms of outdated legislation formalities in many areas such as finance, taxes, trading and transport to name but a few. The combination of exchange rate depreciation and flexibility at the hryvnia's new level is an important step. It is creating the potential basis for Ukrainian businesses to compete again on international markets.

Against the current economic background as described above, this paper is an extension of the research initiated by Grushevska and Notteboom (2015) who used the concepts of intermediacy and centrality in order to assess the role of Ukraine in the global and regional transport networks. The list of key obstacles for Ukraine's intermediacy function was dominated by factors of (i) general nature (e.g. regulatory/ legislative issues, customs formalities, etc.); (ii) port-related

\footnotetext{
* Corresponding author: Faculty of Applied Economics, University of Antwerp, 13 Prinsstraat, 2000 Antwerp, Belgium Email:kate.gr@gmail.com
} 
factors (e.g. high port dues and costs, and seaport legislation); and (iii) inland shipping related (e.g. the legislation on inland waterway transport or IWT). There were other IWT related barriers identified in the analysis, such as: (i) deficient inland waterway infrastructure, (ii) high IWT costs (fees for bridges, locks etc.); and (iii) pilotage charges. It should be noted that the IWT in Ukraine currently is in its infancy in comparison with other land based transport means (rail and road) and with other countries that possess rivers.

This paper intends to enrich the limited academic research on IWT systems in a transition stage, as exemplified by the case of Ukraine.

\section{Scope and approach}

As stated by Grushevska and Notteboom $(2014,2015)$ logistics is a key area to improve Ukraine's competitiveness and to improve the ease of doing business in the country. The seaports in Ukraine play a substantial role in the transport industry and the national economy. The active involvement of the Ukrainian port entities in the effective hinterland distribution of port-generated cargo could bring the port system to a more advanced stage of port system development, i.e. the port regionalization stage as coined by Notteboom and Rodrigue (2005). At the same time such initiatives could increase the competitive position of Ukrainian ports in comparison with other ports serving the same shared hinterland such as Baltic ports (Grushevska and Moskvichenko 2013). Currently the transportation to/from ports is mainly fulfilled by road or by rail based multimodal transport solutions. We believe there is a huge unutilized potential in Ukrainian IWT that needs to be identified and efficiently exploited for the benefit of the national economy (see Figures 1 to 3 ).

The Ukrainian transport system (TS) remains to a large extent ignored in academic literature, Moreover, Ukraine lacks a comprehensive national strategy on transport development. Ukraine has for a long time heavily relied on the two land-based transport modes (i.e. road and rail), but these modes are currently in a progressing defective state (Grushevska et al. 2014, 2016). Grushevska and Notteboom (2015) identified the weak condition of the road system in Ukraine as one of the main bottlenecks (ranked 12 out of 26 bottlenecks) for the Ukrainian transport system. The roads are deteriorating rapidly and their condition worsens further. Given that road and rail are deficient and excessive investments would be needed to ameliorate the situation during several years ahead, we could think of an alternative transport solution for Ukraine. In the early 1990s the IWT was heavily used in Ukraine with a modal share of $3 \%$ to $4.5 \%$, or about 60 million tons per annum. Currently the popularity of IWT dramatically decreased with a share of only about $1 \%$ in the modal split (equal to about 6 to 4 million tons per annum in 2013 and 2014 respectively).

We will conceptually apply the evolutionary and institutional change theories to the case of Ukrainian Inland waterways. In the following section we will present the scope of the paper, followed by the approach and methodology applied in this research. Finally, we will conclude with the findings and future research avenues.

The terms IWT and barge transportation will be mentioned interchangeably in this paper, meaning the same as the multimodal transportation of cargo via inland waterways mainly combined with a pre- or end-haul by truck.
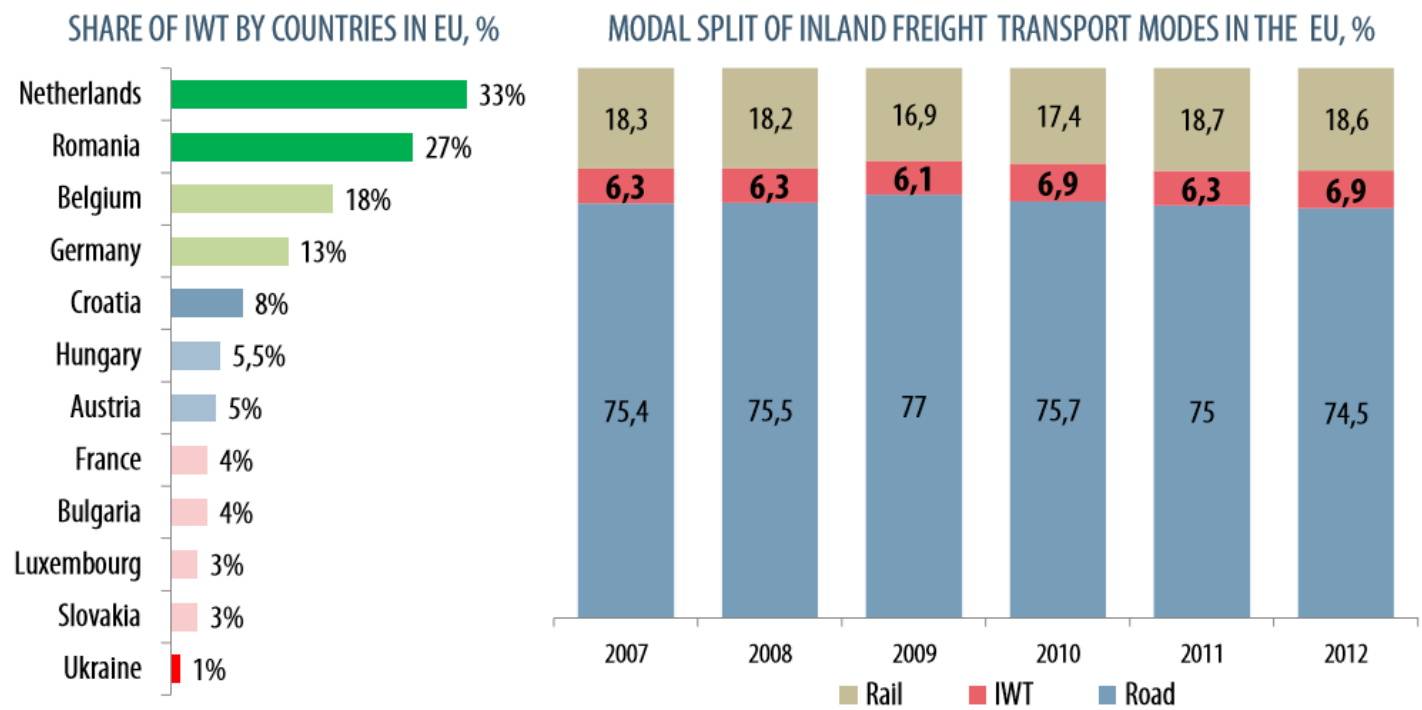

Figure 1. Role of IWT in the European Union (Source: Shkliar (2015)) 


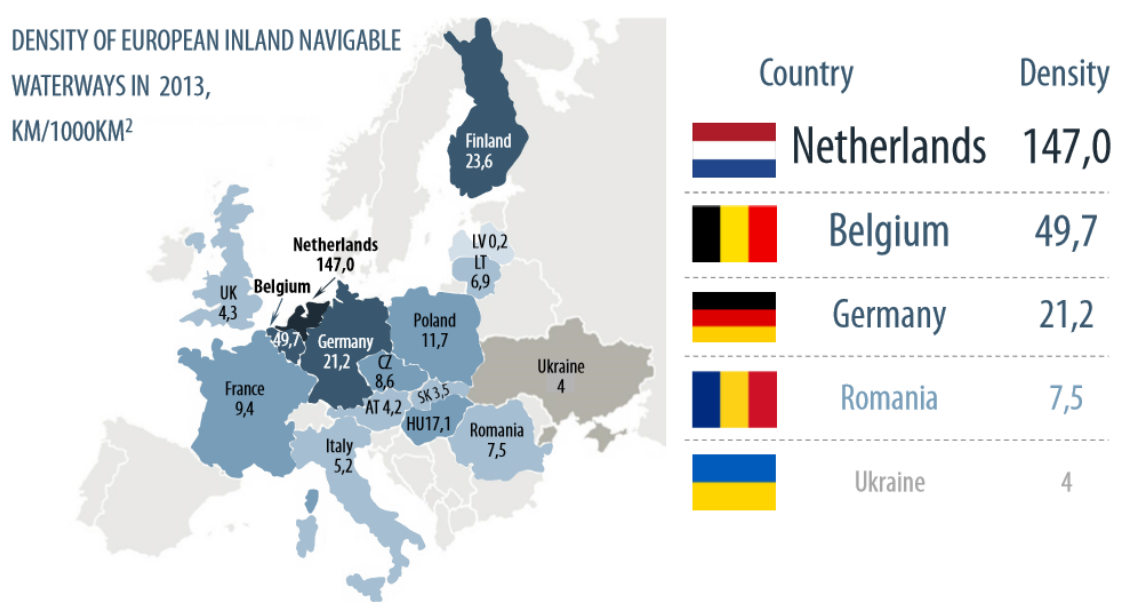

Figure 2. Density of Europe inland navigable waterways in 2013 (Source: Shkliar (2015) based on Bakker Tilly)
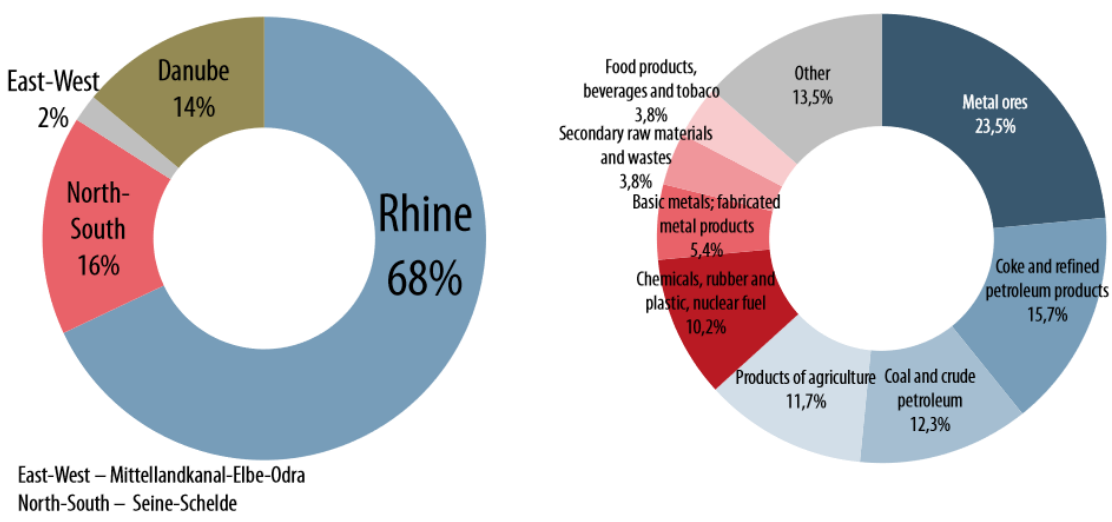

Figure 3. Shares by IWT basins of the EU and the main cargoes transported via IWT in 2013 (Source: Shkliar (2015) based on NEA and Eurostat)

\section{Ukrainian inland navigation market: evolution, terminals, fleet and regulation}

\subsection{Theoretical foundation}

The central research question for this paper is RQ1: What are the critical success factors and opportunities to spur inland navigation on the Dnepr River?

The theoretical foundation of our analysis is based on the evolutionary theory of economic change introduced by Winter and Nelson (1982). The evolutionary theory was selected due to its open system approach and its dynamic essence. First of all, this theory is able to provide insight about the adjustment mechanisms that the ad hoc treatment of disequilibrium adjustment within the orthodox theory (formalization of the broader classic tradition of Western economic thought) does not. Secondly, the orthodox theory lacks the descriptive realism in the characterization of behavior and events. Moreover, it was accurately recognized by leading field academics (Winter and Nelson 1982) that the process of institutional development is an evolutionary process linked to the evolution of firms and industries. Evolutionary theory in a broader sense includes a concern with processes of long term progressive change. Based on the above considerations we select the evolutionary theory as the main theoretical approach for this section. It enabled us to deal with a great variety of complex factors affecting the development of the IWT system in Ukraine and to answer the second research question (RQ2) we like to introduce here: Focusing on the overall chain competitiveness when using the Dnepr River, what are the factors and opportunities influencing the overall performance of inland transportation?

The evolutionary processes analyzed by Fujita et al. (1999) and Fujita and Mori (1997) were associated with the gradual increase of the population size of the economy. The changes in other evolutionary parameters such as transport costs were not taken into account. The agglomeration forces considered in the evolutionary model were related to product variety in goods consumption while no transport elements were considered (such as harbors, rivers, transport network etc.). In another contribution, Fujita and Mori (1996) introduced the water-based transport network into a 
monopolistic competition model of urban systems to show its indispensable role in city formation. The later applications of the evolutionary theory are widely found in spatial economic development discussions (Fujita et al. 1999; Fujita and Mori 1997; Boschma and Frenken 2006; 2009; Boschma and Lambooy 1999; Martin and Sunley 2007; Rigby and Essletzbichler 1997; Mackinnon et al. 2009, Boschma and Martin 2010). These theories later evolved to the notion of evolutionary economic geography (EEG).

A number of studies extensively described the main shipping routes and ports, though the structure and evolution of the global maritime network itself remains less documented (Ducruet and Notteboom 2012). The research on global airline networks is more extensive due to their closer overlap with systems of cities (Guimerà et al. 2005; Derudder and Witlox 2009; Choi et al. 2006). The spatial design of maritime transport not only responds to trade demand but also carries its specific arrangements and network architecture, which also develop over time (Notteboom, 2004). The concentration and regional ramification of cargo flows by load centers and intermediate hubs toward other secondary/inland ports are usual examples of such arrangements.

The evolutionary theory was more recently adopted in a number of works analyzing transport networks (Notteboom and Rodrigue 2005; Lee et al. 2008; Ducruet and Notteboom 2012; Notteboom and Konings 2004, Kreutzberger et al. 2006; Kreutzberger, 2008). Ducruet and Notteboom (2012) introduce the concept of port system to which the theoretical concepts of search (mechanisms shaping the port competition), selection (port selection) and organizational routine (port concentration) are applied. A number of other contributions bring the evolutionary perspective to port based supply chains (Robinson 2002; van Klink 1998; Notteboom 2004; Ducruet et al. 2010) and ports (Jacobs and Notteboom 2011). The latter applied the evolutionary framework to analyze port development by introducing the notion of window of opportunity. Furthermore, the emergence of secondary ports was investigated from the hinterland perspective of a port regionalization process (phase in port and port system development) leading to the creation of a regional load center network (Notteboom and Rodrigue 2005, Nguyen and Notteboom 2016). One of the later applications of the regionalization concept to ports can be found in the work of Grushevska and Notteboom (2014) employed to the Black Sea ports. They concluded that the development of the Black Sea port system cannot be clearly linked to the model developed by Taaffe et al. (1963). The amount of ports has not decreased and the cargo did not concentrate in specific ports (as suggested by the model). On the contrary, the amount of ports in the Black Sea increased and is said to further grow along with the continuing fluctuations of the cargo concentration patterns. Based on the "Anyport model" (Bird 1980) the Black Sea ports are reaching the stage of specialization in their development. The ports have not reached the ultimate stage of "port regionalization" stopping their evolution at the second last phase of their development process (decentralization and insertion of an 'offshore' hub).

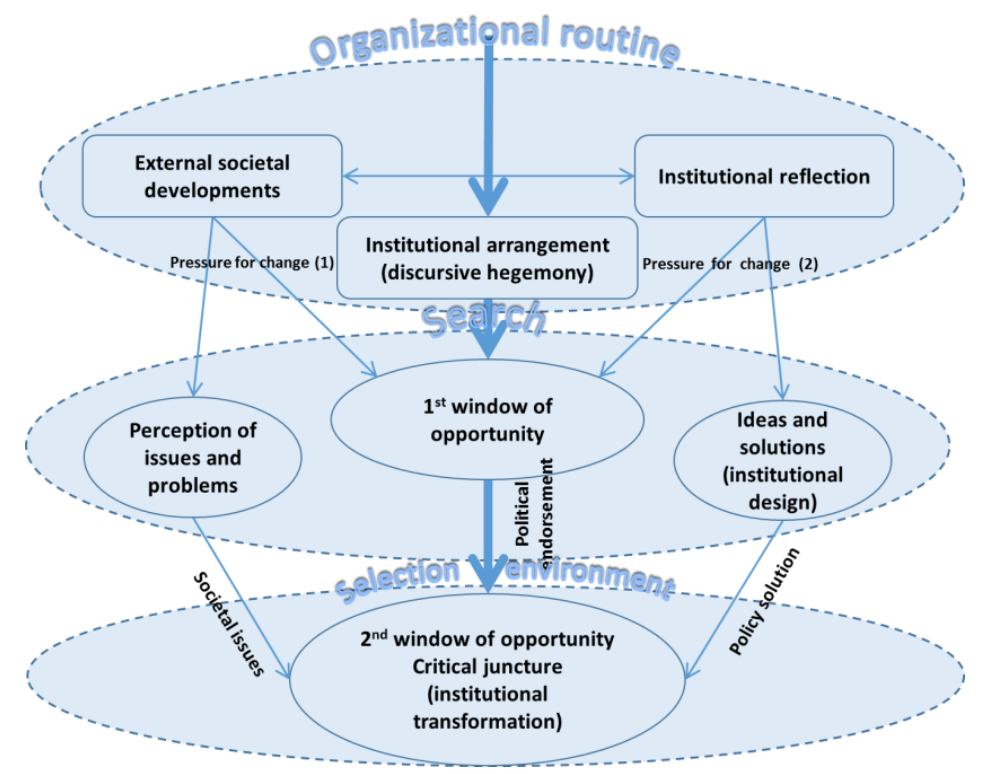

Figure 4. Theoretical framework (Source: Own elaboration based on Jacobs and Notteboom (2011); Winter and Nelson (1982))

As determined by the authors of the evolutionary theory there are three central concepts on which the theory is built on, namely: routine, search and selection environment (Winter and Nelson 1982):

Organizational routine - plays the role of genes of an organization. They result into regular and predictable behavioral patterns of firms. Routines are heritable (future firms are generated from the present ones) and lead to similar 
characteristics between firms. Firms with certain routines can do better than others, so that leads ultimately to the selection process. These circumstances impact the industry state and development over time. There are three types of organizational routine processes according to the evolutionary theory: (i) routine operating characteristics; (ii) period-by-period routines and (iii) routines that modify over time. The first two are acknowledged as routine guided and the last one as the routine breaking processes.

Search - by this term all the organizational activities are denoted which are associated with evaluation of current routines and which may lead to their modification, to their drastic change or to their replacement. The essence of the search resembles to the mutation process from biological evolution theory. The theory protagonists treat the search being partly determined by the routines of the firm (alike in the biological evolution where mutation is driven by its presence in the genes of an organism). The main focus of the evolutionary theory is the changing process by which firm behavior patterns and market characteristics are collectively shaped over time. Profitability operates through firm investment decisions as a main determinant of the expansion and contraction pace of individual firms.

Selection environment - set of considerations that affect the company's wellbeing and the extent to which it expands or contracts. The selection environment is determined by conditions outside the firms in the industry or sector (demand and supply conditions; behavior of other firms, etc.). In reality the search and selection processes are simultaneously interacting phenomena in the evolutionary process: the same aspects that provide selection feedback in the same time influence the directions of the firm's search. The key idea is that the condition of an industry in each time period bears the seeds of its condition in the following period.

We further extend the theoretical framework presented above by the institutional change model of Buitelaar et al. (2007) that was later adopted in the work of Jacobs and Notteboom (2011) and applied to seaport development. Buitelaar et al. (2007) built a theory of institutional change which is a conjunction of evolution and deliberate design. We applied this conceptual model to the core concepts of evolutionary theory and phased them in relation to the concepts of organizational routine, search a selection environment (Figure 4). The organizational routine in this case ultimately triggers the first window of opportunity for change when societal and market developments are considered to be incompatible with the existing institutional arrangement. The institutional reflections by the actors involved (referred to as 'bricoleurs') generate ideas and solutions for the economic dysfunctional or societally incompatible institutional arrangement in what can be referred to as 'institutional design'. The search phase starts when the existing institutional arrangements are successfully challenged and the critical moment for change occurs (1st window of opportunity, critical moment, in Figure 4). Still, this does still not entail that institutional transformation will ultimately take place. At the critical moment, contradictors of change will come up with alternative solutions. Therefore, in order for institutional transformation to be achieved, a second window of opportunity needs to be opened: the critical juncture (Figure 4). This critical juncture emerges, comparable with three matching streams of Kingdon (1995), when the external developments have been translated into recognized problems which are matched by respective (i) solutions and (ii) institutional design which, most importantly, (iii) are politically and institutionally supported and approved. This phase can be traced back to the selection environment of the evolutionary theory, once all the above necessary conditions are matched, the institutional transformation will occur. Usually the institutional transformation will be incremental (entirely new path of development is quite rare). We will base our analysis of IWT of Ukraine on this conceptual model that explains the evolutionary nature of the change in an industry (Winter and Nelson 1982) and as Buitelaar et al. (2007) claim provides "a better understanding of how actions aiming at institutional design are positioned within a perspective of institutional evolution". Remarkably the institutional transformation within this model can be replaced by the organizational routine and organizational forms (Boschma and Frenken 2006; Jacobs and Notteboom 2011).

Certain research has been already carried out (mainly as from 2000) on the intermodal barge transport system (Veenstra and Notteboom, 2011) as well as on rail-based intermodal transportation (Rodrigue, 2008), which both have many fundamental similarities such as limitations to the rail/barge accessibility, pre- and post- haulage and necessity of intermodal transshipment. The theoretical basis of the existing contributions lay outside the evolutionary theory area, more precisely in the field of transaction-cost economics, transport geography, transport demand analysis, multi-criteria-analysis. Besides the intermodal network aspects described in the later section of the paper, the main issues discussed in intermodal transportation research are:

- Land use polices were investigated by Konings $(2008,2009)$ that support the conditions for competitive intermodal freight transport.

- Optimal location of the intermodal barge/rail terminals - particularly interesting is the tool developed by Macharis (2000) for the determination of the terminal location based on the transport demand analysis and multi-criteria analysis (LAMBIT tool).

- Critical success factors for the development of IWT. For example, Frémont et al. (2009) listed the following factors: (i) infrastructure; (ii) market characteristics (the more volumes are transported, the more viable IWT is); (iii) services and terminals (reliable and frequent connectivity, and terminal location close to the market); (iv) end haul 
road transport (acceptable rates for a competitive intermodal full chain cost); (v) the organization of the market (meaning that the shipper needs to be provided an integrated end-to-end service between the deep sea terminal and - the final destination, driving the necessity of coordination among supply chain actors (Van der Horst and De Langen 2008; Panayides 2002). There are only few contributions applying the evolutionary theory to intermodal transportation (Notteboom and Konings 2004; Platz 2009). The last one regarded IWT from the innovative service development perspective at three levels: (i) decision power of shippers and forwarders (micro level perspective), (ii) transport supply/chain perspective (meso level perspective), (iii) political and institutional framework (macro level perspective). Platz (2009) concluded that the next factors are crucial for successful barge transport: (i) bundling in space and quantity (economies of scale effect), (ii) backup transportation (to foresee the unreliability of barge transport when navigation is blocked), (iii) guaranteed lead times, (iv) easy intermodal transfer, (v) complete transport-related service packages and the use of a load unit providing the capacity of a standard semitrailer.

In recent years, the need to connect institutional economics with evolutionary economics for the advancement of the theory is highlighted by the theory main adherents (Nelson 2002; Pelikan 2003). With the current contribution we would like to continue the discussion of Notteboom and Konings (2004) and Grushevska and Notteboom (2014) and contribute to the evolutionary and institutional theory links by applying an integrated approach to the inland navigation market based on the conceptual framework consisting of routine, search and selection environment and windows of opportunities. The aggregation level of analysis will be the meso level that analyses the sector and network dynamics (Boschma and Frenken 2006). This contribution is a genuine application of evolutionary and institutional theory for the inland waterways (or barge-based intermodal transportation) analysis.

\subsection{IWT Evolution}

\subsubsection{Characteristics of the IWT network in Ukraine}

In this section we will apply the earlier introduced three concepts of the evolutionary theory to the IWT system in Ukraine: the organizational routine, search and the selection environment. While the rather mature inland navigation markets of the Danube River and the Rhine are well covered by various academic and technical studies, the Dnepr River function remains not so well investigated. The purpose of this chapter is to highlight the evolution of organizational routine and the search phenomena of the IWT within Ukraine, as well as within international transport corridors as selection environments. The comprehension of the evolutionary nature of Ukraine's IWT will allow us to depict the existing and missing seeds for the IWT system expansion in the future periods.

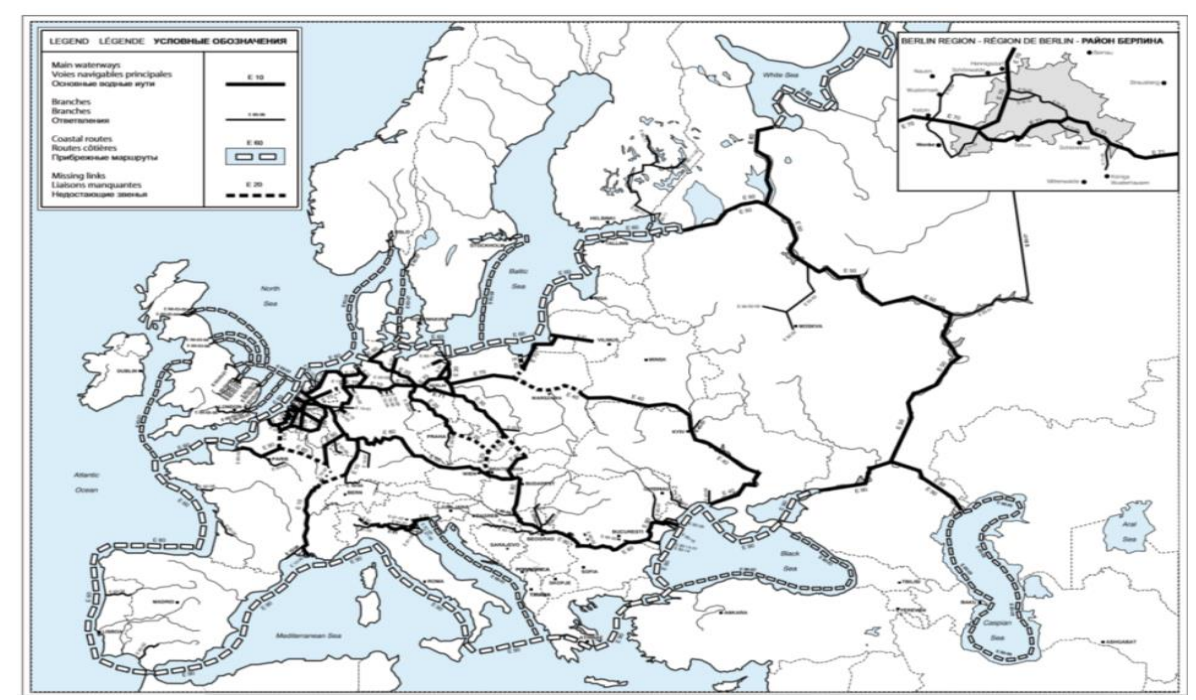

Figure 5. Scheme of the Network of the E Waterways in Europe (Source: Blue Book, United Nations 2012)

The total length of Ukrainian inland navigation network is $2130 \mathrm{~km}$ and consist of the following rivers: Dnepr, Danube and Southern Bug Rivers. All these rivers have the category "E" according to the international system of classification of waterways, which make them a unique deep water river system. At the national level the Dnepr River should play an active role in connecting the central part of the country including Kiev to the southern part of the country with the Black Sea. The Dnepr and Danube Rivers represent a connecting link and potential extension of the following 
European multimodal corridors: (i) TEN-T corridor Rhine-Danube (or also called 7th Pan European corridor) using the Ukrainian Danube ports, (ii) TEN-T corridor North Sea-Baltic, extending the corridor via the rail connections from Poland to Ukraine until Kiev, where cargoes are shifted to river transport (iii) Baltic-Adriatic (or also called 9th Pan European corridor) that could be similarly extended as North-Sea Baltic corridor (already a container train service exists connecting Baltic with Black Sea-Viking train, Grushevska and Notteboom 2015) and finally the Asian-European corridor connecting the central Asia with Europe (iv) TRACECA intermodal corridor, could include the barge-based intermodal transportation via Ukraine (see Figures 5 to 7).

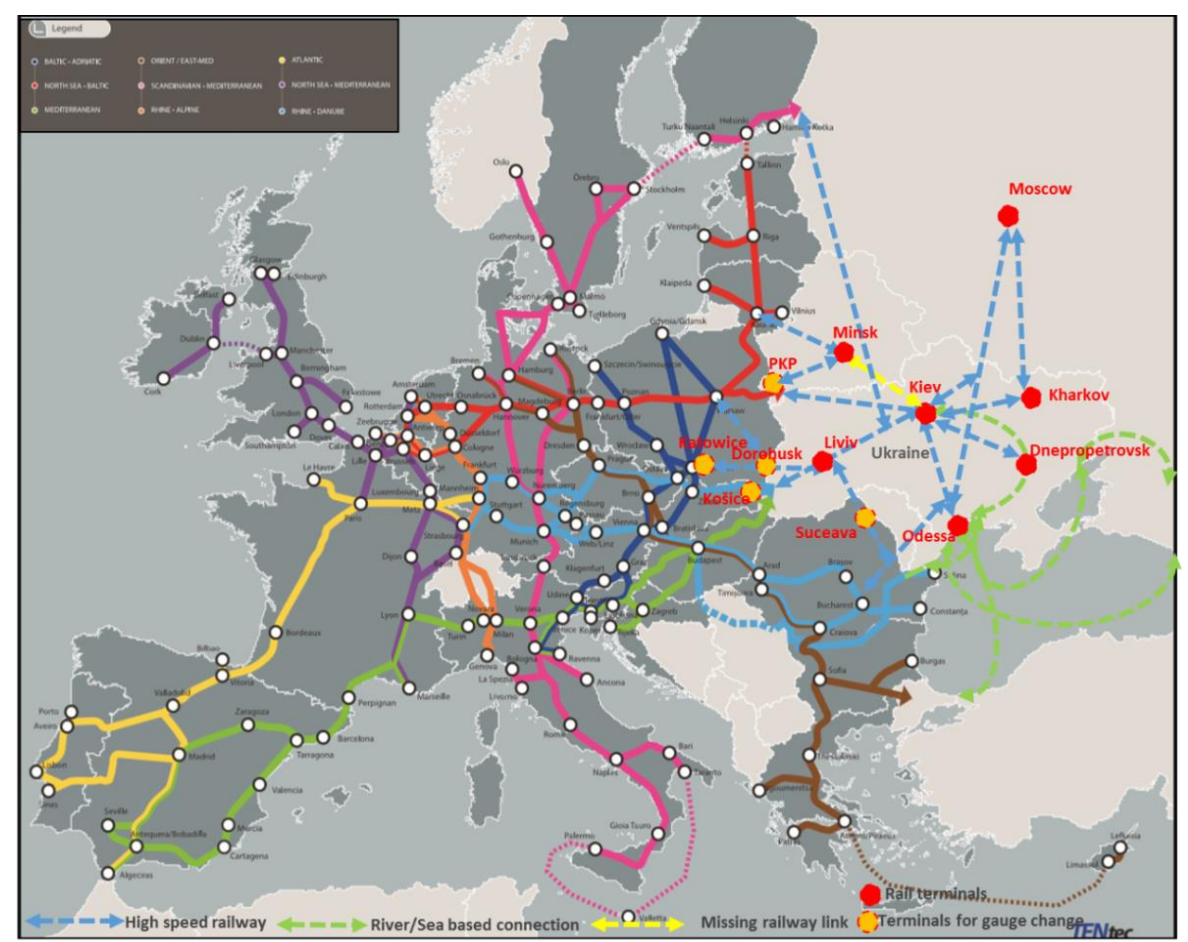

Figure 6. TEN-T networks and the links to Ukrainian transport system (Source: Own elaboration based on TEN-T networks)

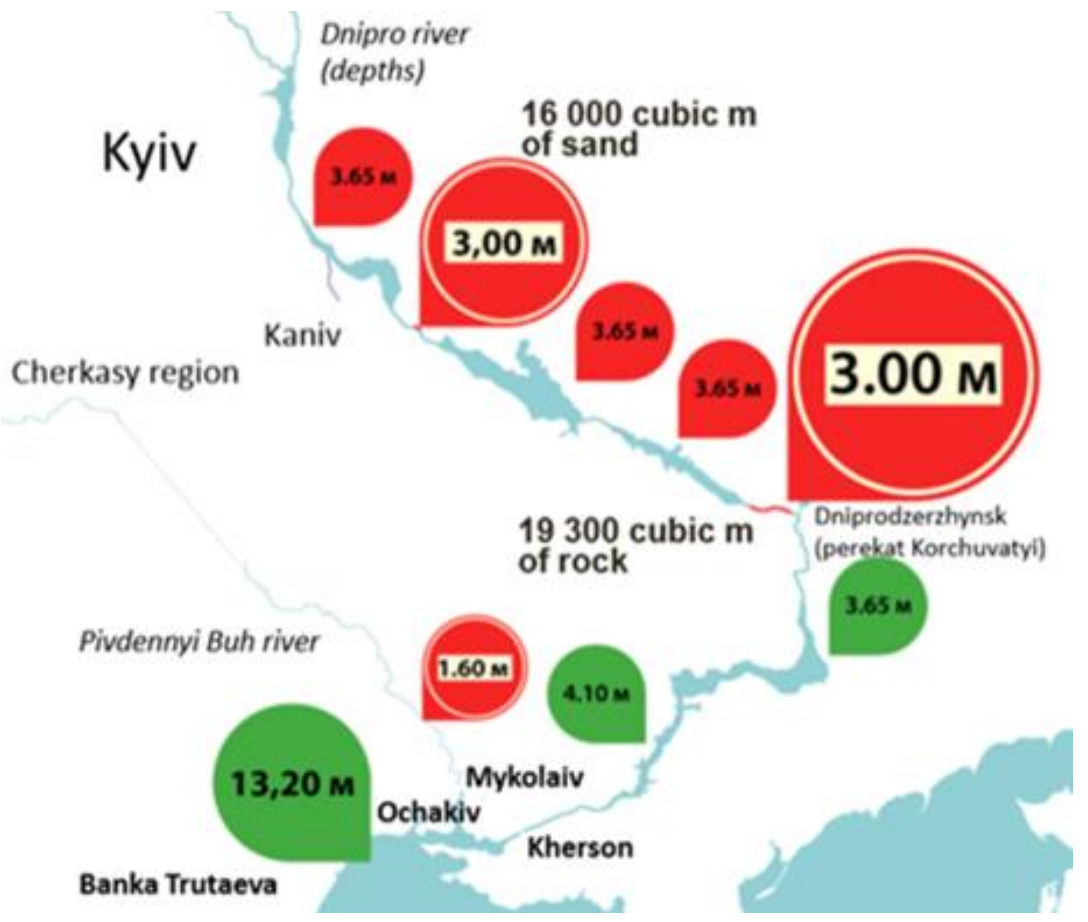

Figure 7. Dnepr and South Bug maximum navigational drafts (Source: Ukragrocom) 
It should be noted that there are few missing links and nodes in this map: Minsk - Kiev high speed rail connection is missing. The available rail terminals in Ukraine (Liski Kiev, Liski Dnepropetrovsk and Liski Odessa) are located slightly far away from seaports and have the reputation of an overpriced and bad service. Ukraine could extend the TEN-T reach provided if (i) the corresponding logistics infrastructure is developed; (ii) the reliable service at the existing trans-loading/intermodal terminals is delivered (at the border with Ukraine in Poland, Slovakia, Romania, Belarus) and (iii) a favorable regulatory framework is implemented by Ukrainian public parties. In this context Ukrainian IWT may play an essential role in logistics chains connecting the Rhine-Danube and the North Sea-Baltic Sea and Baltic-Adriatic rail/road TEN-T corridors with other Sea basins and regions (e.g. Baltic, Black and Mediterranean Seas, Russia and Central Asia). A water-based connection up to Central Asia for vessels navigating down the Dnepr River would be as follows: sail via the Black and Azov Seas, then follow the Don River and the Volga-Don canal up to the ports of the Volga River and Caspian Sea.

The Dnepr is the third longest river of Europe (after Volga and Danube) and has a great potential for an active role in national cargo transportation. The Dnepr starts in Belarus and crosses Ukraine in a curve from South to North passing by the main cargo generating regions in the country. It takes part in the European River corridor E40. Currently, the waterway between Dnepropetrovsk and Kiev is almost unused for navigation due to unreasonable high costs for passing the locks, for opening the railway bridges and some draft limitations. Kiev and Dnepropetrovsk have tiny rifts limiting vessel draft to $3 \mathrm{~m}$, while overall draft it is up to $3,65 \mathrm{~m}$. As a result of these factors the biggest part of the Dnepr River is currently unexploited. The transportation of goods from Dnepropetrovsk to Kyiv and further to Belarus is almost absent.

The Danube: The ports located on the Ukrainian Danube are officially considered as sea ports: port of Reni, port of Izmail and port of Ust Dunai'sk. All the ports are state-owned and are connected to the Black Sea via the canal Bystroye. There are no locks or bridges in the Ukrainian part of the Danube. The Danube represents a component of European River corridor E80.

The Southern (Yuzhnyi) Bug: The source of this river lays in the West from Dnepr, in the Volyn-Podillia Upland in Ukraine, close to the Polish border, from where it flows southeasterly into the Bug Estuary (Black Sea basin) through the southern steppes. It is $806 \mathrm{~km}$ long but the main navigable area on the Bug is until ports of Nikolaev and Nikatera (35 km upwards from the Black Sea).

There are many river ports and terminals along the banks of the Dnepr and Yuzhny Bug River (about 23 in total). Ukraine's ten oldest and major river ports are: Chernigov, Kiev, Cherkassy, Dneprodzerzhinsk, Dnepropetrovsk, Zaporozhie, Nikopol, Novaya Kakhovka, Kherson and Nikolayev, used to handle up to 100 million tons of cargo annually in former Soviet Union times. The Dnepr is the only river in Ukraine with navigation locks.

\subsubsection{Stages in the development of IWT in Ukraine}

The evolution of Ukrainian IWT is characterized by specific discursive hegemony forms that can be divided into three routine stages that modified over time based on the industry transformation and adaption each having different search and selection environments:

\section{First stage (before 1992)}

During USSR times, the rivers of Ukraine were well maintained and actively used. At the end of the 1980 s — the beginning of 1990s there were about 50 million tons transported by IWT of mainly industrial cargoes. There were two Soviet state river shipping companies involved in IWT namely Ukrainian Danube Shipping Company (UDSC) and Ukrrichflot. In the 1980s, the Soviet Danube Shipping Company (SDSC) was a large and complex enterprise. Only its transport fleet numbered more than 1000 units with deadweight of about $1 \mathrm{mln}$ tons. The annual volume of the shipping operations amounted to 11.5 - 12 mln tons. UDSC served mainly the Danube Ports (incl. the Ukrainian Danube ports of Izmail, Reni and Ust-Dunaisk) up to North Sea and other ports in the Black, Mediteranean and Azov Seas further up to Caspian Sea via the Volga-Don canal. Ukrrichflot in its turn served mainly the Ukrainian market via the Dnepr and Southern Bug ports.

\section{Second stage (1992-2008)}

After the downfall of the USSR and the subsequent economic crisis, an enormous withdrawal of river tonnage took place. That forced shipping companies to seek for new cargoes in other regions outside of Ukraine. In the ten years following the breakdown of the USSR, river traffic reduced by about ten times. The Joint stock company Ukrrichflot became the main river carrier within Ukraine. In 2004, the company's transported cargo volume was 2,4 million tons.

The second big shipping company of Ukraine changed its ownership as well. UDSC or "Ukrainian Danube Shipping Company" operates mainly outside of Ukraine and its traffic volumes in 2005 represented a share of $25 \%$ of the whole transport activity in the section of $2400 \mathrm{~km}$ from the mouth of the Danube river up to the port of Kelheim, Germany 
(Doubrovsky 2005).

Except the considerable institutional, regulatory and economic changes at the national level, there were specific IWT industry changes. The ownership and the structure of inland shipping companies and inland ports entirely changed. As early as in 1992, Ukrainian river ports began to be operated in joint-stock ownership. And in 2002, already four of the river ports (i.e. Zaporozhie, Dnepropetrovsk, Kherson and Nikolayev) were integrated into JSC Ukrrichflot which currently owns a substantial share of these ports' shareholdings.

\section{Third stage (2008-now)}

At the end of 2008, Ukraine was severely hit by the world economic crisis. Nevertheless, local shipping companies managed to capitalize during the yearly 2000 and ordered a certain amount of vessels at mainly Ukrainian shipyards. As from 2008, the new vessels started to be delivered to join the remaining obsolete fleet. Only two companies at this stage were involved in the fleet upgrade: Ukrrichflot and Nibulon. JSSC Ukrrichflot in 2009 started the construction of its mixed navigation fleet ('sea-river') to transport general and bulk cargo. Nibulon, being a vertically integrated grain holding, ultimately constructed a significant fleet of barges and tug boats for its grain transportation. The overall number of ships in the Ukrainian fleet dropped significantly. The current average age of Ukrainian inland vessels exceeds 25 years.

At present, the IWT system is quite outdated:

- There is a lack of bunkering facilities in the river ports;

- The majority of ports lack container handling equipment. Only Nikolaev, Dnepropetrovsk, Zaporozhye and Aquarelle ports have container facilities in place;

- The available river fleet is quite obsolete;

- There is a great need for river dredging and the maintenance of navigation equipment (buoys, lights etc.)

\subsection{Market structure of IWT}

\subsubsection{General market outlook}

Looking at the IWT market and applying the extended inland navigation market structure introduced by Bellen (2011) we found the following actors in the IWT market in Ukraine. Each group of actors and their current organizational routines will be described later in more detail:

- Independent shipping Co: Ukrrichflot (about 142 vessels); UDSC (514 vessels); Tavria Line (2 vessels); Commercial fleet of Donbas (2 vessels); MD shipping; KDM Shipping; Enire; Ocean Stevedoring; Transship.

- Charterers: these are mainly the grain traders such as Hermes trading and Ukragrokom, Kernel, Topfer etc.

- Own account operators: Nibulon (28 barges and 7 tugboats), Unigrain

- Shipyards: Integrated in the Ukrrichflot and Nibulon Companies; and few other private and state owned shipyards.

- Inland ports/terminals

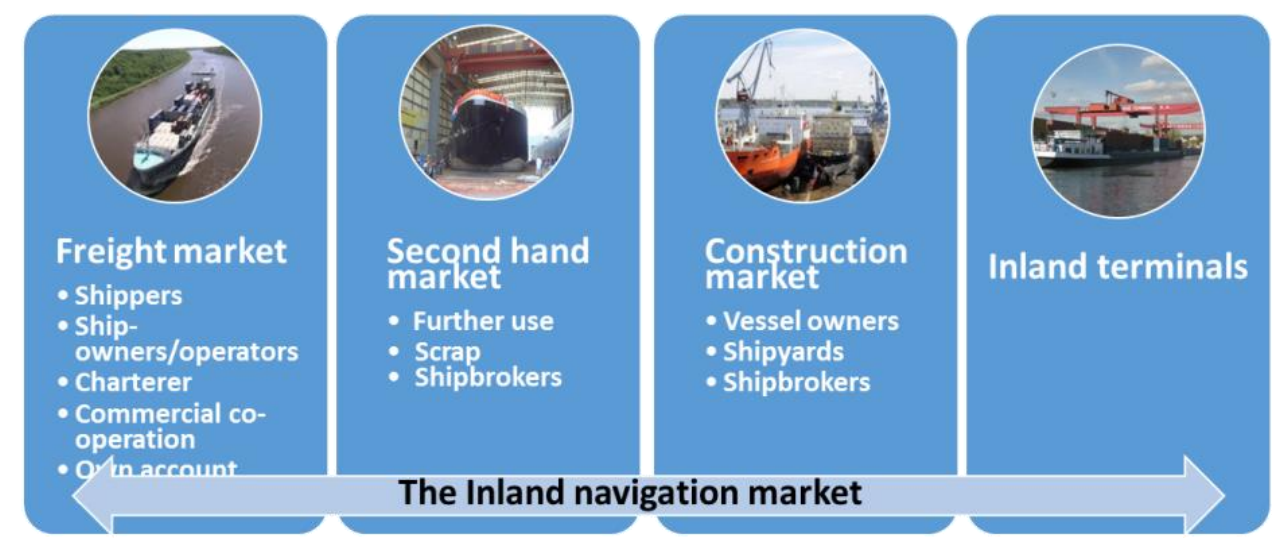

Figure 8. Inland navigation market (Source: Own elaboration based on Beelen (2011))

\subsubsection{Terminals and terminal operators}

As an outcome of the routine settings, search and selection processes occurred in the IWT evolution stages the 
system or river ports and terminals is very diverse. Officially there are 17 private river ports and terminals on Dnepr River (12 river ports and 5 river terminals) and four sea ports on Southern Bug River (Nikolaev, Kherson are state owned; Nibulon and Nikaterra privately owned). There are three ports located on the Danube River that have the status of deep sea ports (but actually act as inland ports) and are in state ownership (Izmail, Reni, Ust-Dunai'sk) see Figure 9.

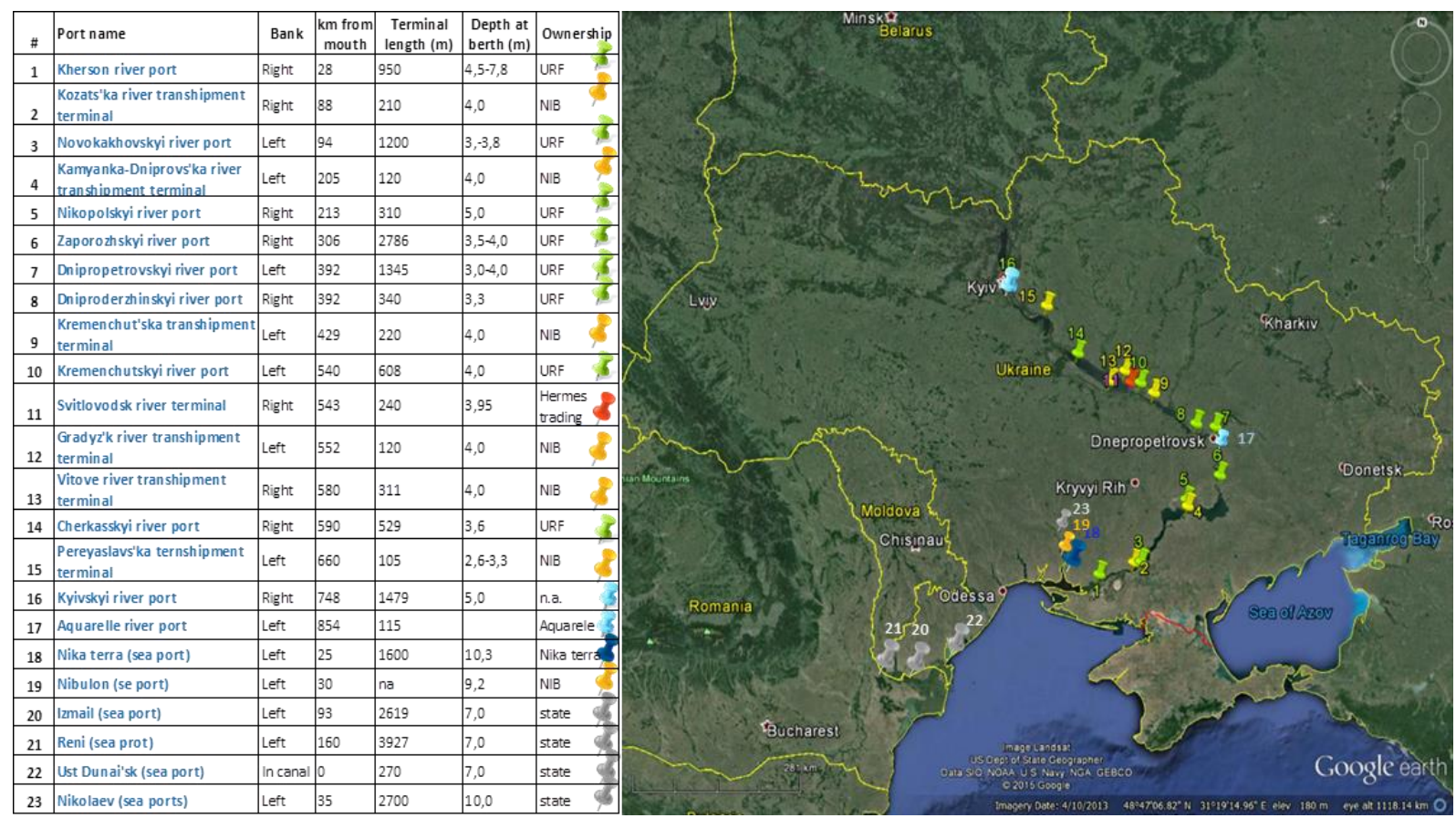

Figure 9. Terminals and ports located on Ukrainian IWW (Source: Own elaboration based on Egis International, Dornier Consulting (2013))

There are several big terminal operators in the Ukrainian IWT such as (i) Ukrrichflot which is a vertically integrated terminal operator and shipping company with 8 diversified ports, (ii) Nibulon which is the domestic vertically integrated grain holding owning 7 specialized grain terminals) and (iii) Administration of Sea ports of Ukraine - ASPU with one port located on the Southern Bug, one on Dnepr and three on the Danube. The remaining terminals are owned and operated by smaller private entities.

The current condition of inland ports evolution path is quite different but generally speaking the following features are common for the big majority of inland ports:

- River ports lack suitable handling equipment for containers. The only operational river container facility is located in Dnepropetrovsk area (i.e. ports of Aquarelle, Dnepropetrovsk and Zaporozhskyi river ports on Dnepr and Nikolaev on Southern Bug).

- The Nibulon grain terminals are well equipped and maintained.

- Ukrrichflot river ports up until Dnepropetrovsk are actively used and relatively well equipped. The remaining ports have quite outdated handling and port facilities.

- The ASPU ports on Danube and Dnepr have fairly aged port facilities. Kherson sea port which has the best drafts on the Dnepr river (up to $8 \mathrm{~m}$ ) lacks a suitable transshipment base for handling cargo between river- and sea-going vessels.

- The remaining few terminals in hands of smaller players are in an adequately technical condition.

\subsubsection{Fleet}

In comparison with the previously available the Ukrainian fleet is presently quite obsolete. That is the outcome of evolutionary forces during the second and third evolutionary stages namely (i) routine and (ii) search (characterized by a lack of investment in shipbuilding, and selling and scrapping under questionable grounds of originally existing state-owned fleet) and (iii) selection environment (lack of attractive regulatory and institutional frameworks for the IWT development; cheaper alternative of land based transport modes). The last one continuously driving the continuous companies' and ultimately industry's shrinking. 


\section{General outlook}

However, if we look at the Ukrainian inland fleet in comparison with other national and regional fleets, the Ukrainian one seems meaningful. The main types of cargo carried by the inland fleet were, and to a certain extent, still are: metals, steel, grain, sand and other bulk cargoes.

Figure 10 and Tables 1 and 2 present the inland fleet in Ukraine in comparison with other countries. Statistics exhibit the inland fleet by each country located along the Danube and Dnepr rivers. The comparative display gives a good understanding of other countries' fleet and the relative share of Ukraine in the total operational fleet in the basin.

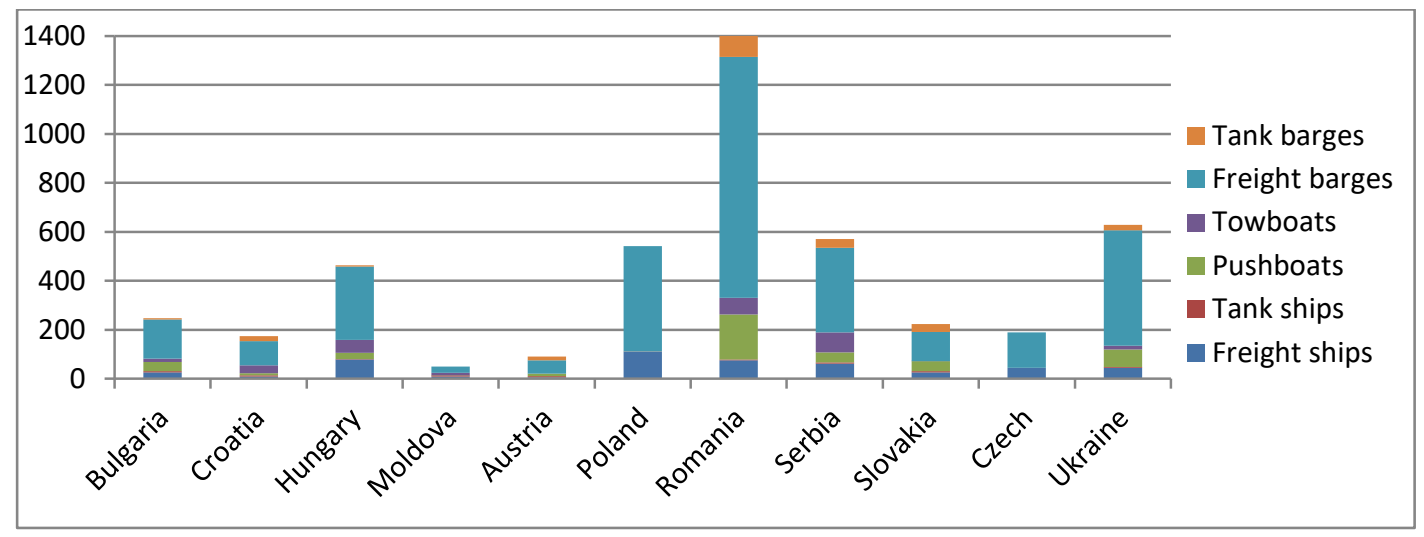

Figure 10. Inland fleet of the Dnepr and Danube basins 2012 (Source: Gunthner Ginkels (2015))

Table 1. Evolution of the IWT fleet in in Ukraine (Source: Ukrstat)

\begin{tabular}{lcccc}
\hline & & & 2010 & 2013 \\
\hline Total Fleet, units: & 1990 & 2000 & 904 & 635 \\
Oil tankers & 29210 & 1670 & 52 & 40 \\
Bulkers/ barges & 6192 & 90 & 111 & 28 \\
Bulkers & 6626 & 266 & 526 & 400 \\
Container vessels & 10568 & 681 & 2 & 214 \\
Others types (tugs etc.) & 5225 & 386 & 7 & 167 \\
Total traffic, mln t & 66 & 8 & 1814 & 4 \\
\hline \multicolumn{1}{r}{ Total } & 58488 & 3347 & & 1276 \\
\hline
\end{tabular}

Table 2. Inland fleet of the European river basins 2012 (Source: Gunthner Ginkels (2015))

\begin{tabular}{|c|c|c|c|c|c|c|c|}
\hline Country & $\begin{array}{l}\text { Freight } \\
\text { ships }\end{array}$ & $\begin{array}{l}\text { Tank } \\
\text { ships }\end{array}$ & $\begin{array}{l}\text { Push } \\
\text { boats }\end{array}$ & Towboats & $\begin{array}{l}\text { Freight } \\
\text { barges }\end{array}$ & $\begin{array}{c}\text { Tank } \\
\text { barges }\end{array}$ & Total \\
\hline $\begin{array}{l}\text { Scheldt-Rhine countries (BE, DR, FR, } \\
\text { LUX, CH) }\end{array}$ & 6600 & 1990 & 1132 & 631 & 2541 & 155 & 13049 \\
\hline $\begin{array}{l}\text { Central - East Europe (BG, HR, H, MD, } \\
\text { A, PL, Ro, SRB, SK, CZ, UA) }\end{array}$ & 486 & 39 & 422 & 275 & 3135 & 233 & 4590 \\
\hline - Ukraine & 44 & 3 & 73 & 15 & 472 & 22 & 629 \\
\hline - Share of Ukraine & $9.1 \%$ & $7.7 \%$ & $17.3 \%$ & $5.5 \%$ & $15.1 \%$ & $9.4 \%$ & $13.7 \%$ \\
\hline
\end{tabular}

The prevailing inland fleet arrangements in Ukraine is an outcome of the distinguished three routine stages shaped by the corrsponding search and selection environment outcomes of the following shipping companies:

Nibulon. Nibulon as previously mentioned it is a local vertically integrated grain producer and trader. The fleet owned Nibulon count about 35 units (28 barges and 7 tugboats).

Ukrrichflot. Ukrrichflot is a shipping company with its own river port infrastructure which provides integrated logistics solutions using the Dnepr river. Ukrrichflot is the major transport operator on the Dnepr river, owns, manages and operates more about 124 units of commercial cargo river tonnage, enabling the company to provide high quality service for its clients mainly withing Ukraine. The fleet is one of the key links of the integrated logistic chain. The fleet of Ukrrichflot consists of three main groups (Ukrrichflot official website):

- River fleet performing carriage via the Dnepr and Danube river, with entry into coastal sea waters. 
- Sea-river - Conventional fleet performing carriage between river ports and ports of other countries in international trade transactions.

- Tugs and auxiliary-service fleet which are engaged in additional (auxiliary) services (such as bunkering, collecting sludge/bilge, towing, etc. at the company's ports).

UDSC. The river fleet of the Ukrainian Danube Shipping Company comprises a river fleet makes up 91 self-propelled vessels and 423 units of the non-propelled fleet. Furthermore, the fleet of the foreign joint-ventures comprising 125 non-propelled units is in operation of the UDP. The characteristics of the fleet are:

- river barges of various types with a cargo capacity ranging from 1000 up to 2300 tons;

- river tugs-pushers;

- self-propelled dry cargo vessels with a cargo capacity of 1814 tons which are also used for pushing of the barge convoys.

The river fleet of the UDSC fulfils shipment of various cargoes such as iron ore; coal and coke; grain cargoes; metal and various general cargoes; fertilizers in bulk and packaged; oil products; machinery and equipment; vehicles; cargo in containers; large dimension and heavy cargoes.

The UDSC fleet operates along the whole navigable section of the Danube river from the port of Ust-Dunajsk (Ukraine) and Constanza (Romania) up to the port of Kelheim (Germany) and in the reverse direction. In addition to river transportation, the UDSC river fleet performs shipments of large project cargoes and heavy lift cargoes in the sea and the mixed river - sea service and from the Mediterranean Sea to the Caspian Sea as well as to the IWW ports of Russia.

Others. The commercial fleet of Donbass Ltd performs two basic activities: shipment of general and bulk cargoes by its own vessels and rendering management services for the vessels of other companies. The company's fleet consists of two vessels with general deadweight 9,000 tons. The commercial fleet of Donbass ensures delivery of cargoes of domestic and foreign charterers all over the world.

Tavria live owns and operates two container sea-river vessels offering service between Constanza and Dnepropetrovsk. The vessels' capacity is about 112 TEU (empty) and 92 TEU (loaded).

\subsubsection{Regulatory aspects of inland navigation in Ukraine}

According to the evolutionary theory, the regulatory and institutional changes are triggering the change of the selection environment in which the IWT actors coexist. IWT in Ukraine is quite complex. The main regulatory body for the river transport in Ukraine is the State Sea and River Transport Policy Department of the Ministry of Infrastructure. There are also other major regulatory players of Ukrainian IWT including:

Ukrvodshliakh: The state-owned enterprise is responsible for the development of public inland waterways and aims to create the conditions required to guarantee a safe navigation. This enterprise responsible for the implementation of policies relating to transport, technical requirements and the environment in the operation of the waterways and navigable locks in Ukraine. Moreover, this body collects the lock passage dues and maintains the lock located on the Dnepr River. However, the locks are part of the of the energetic complex, namely they are hydroelectric stations used by "Ukrhidroenerho" enterprise - the state company of Ukraine that manages the hydro power plants along Dnieper and Dniester rivers.

Ukrmorrichinspektsia: Is directly subordinated to Ministry of infrastructure of Ukraine whose main tasks are: (i) implementation of state policy in the field of safety at sea and river transport; (ii) provision of the safety in the IWW of Ukraine; and (iii) the provision of administrative services in the field of maritime and river transport (e.g. issuance of port calls permits for foreign flag vessels). Both institutional arrangements (Ukrvodshliakh and Ukrmorrichinspektsia) are archaic locked-in institutional arrangements (hegemonic discourse) that experienced limited modification and evolutionary adaptability.

River Information Service of Ukraine (RIS): RIS services the Dnepr basin (from Kizomys to Vyshgorod) and Danube section of waterways and became operational in 2012. RIS originates from an EU framework directive introduced in 2005 that provides minimum requirements to enable cross border compatibility of IWT national systems. RIS of Ukraine is a branch of the state enterprise Delta-Lotsman, which in its turn is a part of the state enterprise 'Administration of Seaports of Ukraine' (ASPU) (RIS in Ukraine was created by the order of the Ministry of Infrastructure of Ukraine of 25.02.2011 No.7 ).The main responsibilities of RIS include: the improvement of the level of safety of vessel traffic; managing the efficiency of shipping by inland waterways and environmental protection; the improvement of interaction with other modes of transport by providing vessel owners and all authorized users the RIS web-site based information with real-time status on shipping condition of the Ukrainian IWW and any other relevant factors that may affect navigation in RIS zones on the Dnepr and Danube Rivers. The adoption of the contemporary information systems in Ukraine compatible with the EU requirements represent an adaption process of the institutional arrangements of Ukrainian IWT. 
New law on IWT: During the third evolutionary stage of IWT in Ukraine existing organizational routine was strongly debated by the IWT stakeholders. A strong institutional reflection has taken off. As a result, during the last years the strong perception of issues and problems has been created and possible ideas and solutions for a different institutional design of IWT have been formulated. The above described has generated the opening of the $1^{\text {st }}$ window of opportunity in the search challenge.

The sizable outcome of this deliberation is draft law on IWT of Ukraine being currently under deliberation in the Cabinet of Ministers of Ukraine. The draft was jointly produced by the majority of the stakeholders involved in the IWT in Ukraine. The expected implementation of the law is forecasted for the first half of 2016. The main purpose of the new law on IWT of Ukraine the following perceived problems working out: (i) liberalization of the IWT system for navigation, and (ii) elimination of the bureaucratic formalities levied on vessels operating in the Ukraine. Some of the main policy solutions in the new law are as follows:

Formation of the IWT administration that will be directly subordinated to Ministry of infrastructure of Ukraine. The Ukrvodshliah body will be removed and its function will be levied on the IWT (e.g. river maintenance).

- Abolition of the payments for lock and bridge openings. The maintenance of locks will be fulfilled from the extra premium from the electricity sell which is produced at the power plants that use the locks for energy production.

- Cancellation of the canal dues for vessels with a draft smaller than $4.2 \mathrm{~m}$.

- Introduction of a unified "vessel due" that will replace the numerous charges used before. However, it is still not clear what will be the method and the size of this "vessel due".

- De-monopolization of the obligatory all river long pilotage services currently rendered by the state owned pilotage company "Delta lotsman".

- The extension of the navigable period, since before the navigation was allowed only eight months a year from March 25 to November 30. The new law allows the navigational period to be determined bases on the actual weather and ice conditions that could ultimately lead to a greater navigational period of 10 months instead of 8 as before.

- The law will be the basis for the following National Strategy of development if IWT.

- The initiation of the aforementioned law represents a huge step towards the right direction but still there remains a certain vagueness. More precisely the new law on IWT is heavily dependent on the coming national IWT strategy which makes the IWT law very ambiguous.

\subsubsection{Regulatory practices in IWT of Ukraine: their impact on the intermodal competitiveness of IWT}

The regulatory practices are the strong forces shaping constantly the IWT selection environment. Moreover, they constitute the basis of institutional arrangement namely the regulative and normative pillars (Scott 2001). The third institutional pillar namely cultural-cognitive is not explicitly discussed in our paper. These locked-in institutional pillars negatively affect the costs connected with calling inland ports in Ukraine. Figure 11 presents some of the components of the disbursement account of the vessel.

Excessive additional expenses on pilotage, locks, bridges and one-time permits make transportation on the Dnepr river more expensive than rail and/or road transportation.

Port dues and charges are levied based on the Decree of the Ministry of infrastructure \#316 from 20. 05. 2013. Port dues for vessels in international navigation are 10 times higher than for vessels in cabotage navigation under national flag. The port dues and charges for the foreign flag vessels are 10 times higher than for national flag vessels. On average for a vessel with a tonnage of 2930 tons the fees will be 1.36 per ton.

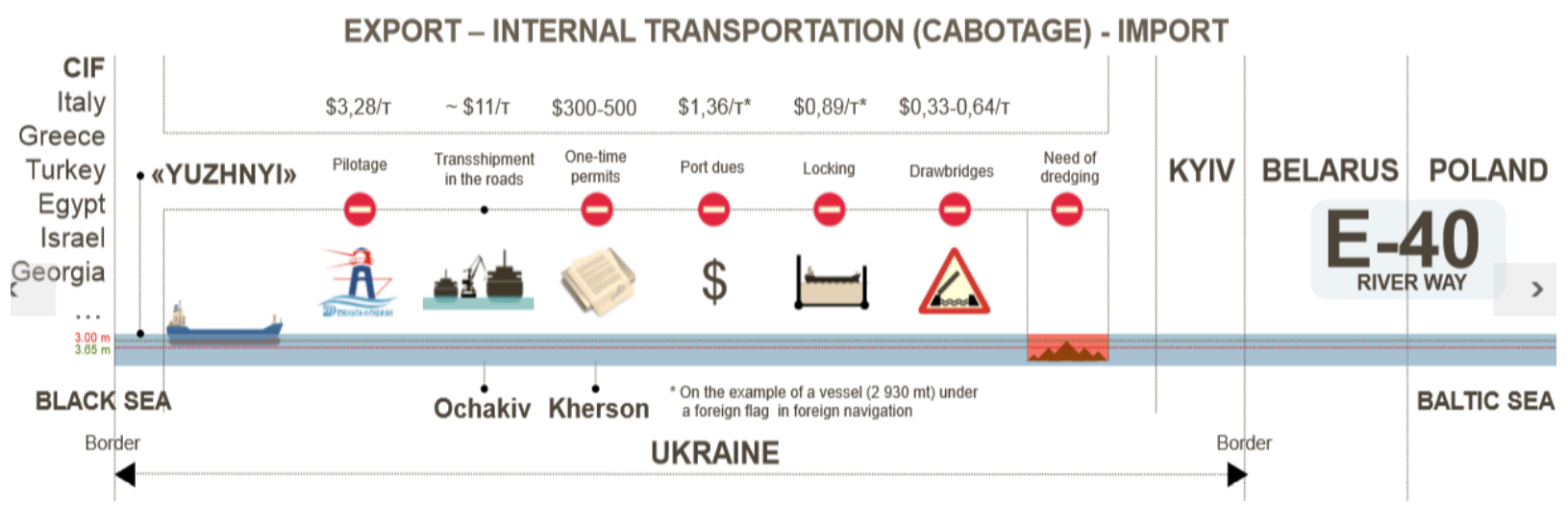

Figure 11. The approximate costs of navigation on the Dnepr river / Unit: \$/tone (Source: Ukragrocom) 


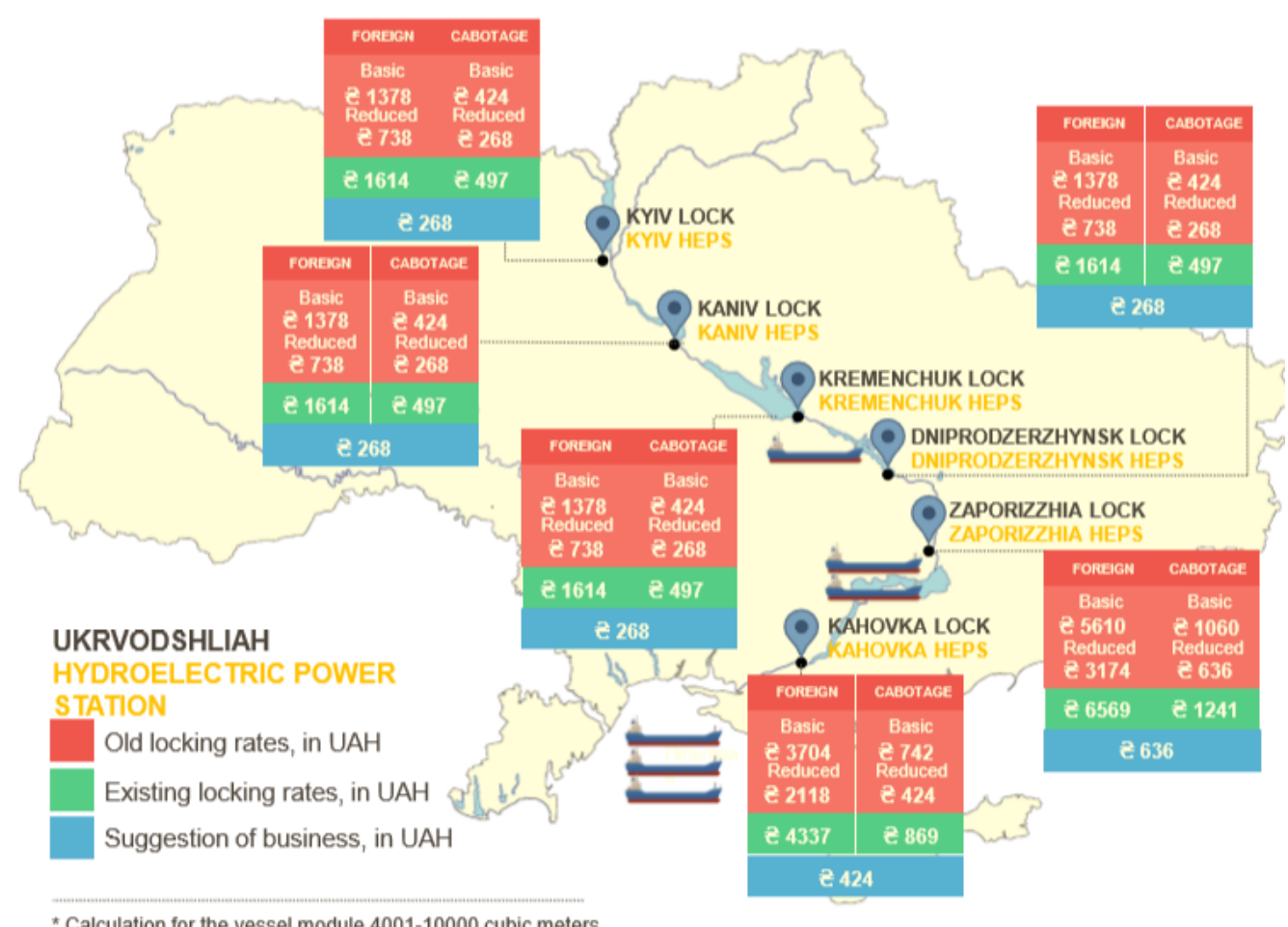

Figure 12. Locks passage fees on Dnepr for national and foreign flag vessels (Source: Ukragrocom)

Pilotage fee is based on the Decree of the Ministry of infrastructure \#9655 from 03. 12. 2013. Currently pilotage is a compulsory service rendered by Delta-Lotsman along the whole river. This makes the pilotage service exceedingly expensive. Moreover, there are significant surcharges to the base tariff such as for night-time operations $(+25 \%)$, for weekends $(+50 \%)$ and weekend night time $(+100 \%)$.

A lock passage fee is levied based on the Resolution of the Ministry of infrastructure \#236 from 22. 02.1999. Navigation on the Dnepr River means passing a number of locks, including Zaporozhe single lock (with a water drop of $37.5 \mathrm{~m}$ in the lock), which is the 3rd highest lock in the world. There is a large difference of lock passage fee for national flag and foreign flag vessels. Regardless of the vessel flag the ultimate cost per ton (a vessel of up to 3000 tons) is $3 \$$ per ton.

A bridge opening fee is based on the clause \#99 of the Ukrainian Railways (UZ) Statute. Every vessel with a height above the maximum of $8.5 \mathrm{~m}$ and $9.7 \mathrm{~m}$ (passing the Kremenchug and Dnepropetrovsk bridge respectively) is obliged to pay the bridge opening fee. That significantly strains inland shipping.

A port call permit fee is levied based on the Decree of the Ministry of infrastructure \#665 from 09. 11. 2012. Every foreign flag planning to call an inland port or terminal has to apply for one time permit issues by the Ukrmorrich inspection.

\section{Discussion and Conclusion}

In virtue of the carried out research in the first part we see our work as an original contribution as it applies evolutionary theory to the inland navigation market through an integrated approach based on the concepts of routine, search and selection environment. Regionalization of the deep-sea ports of Ukraine and the subsequent development of the river-based transport chain can lead to the development of a regional load Centre network. The above will be feasible under the condition that the current and following search and evolving selection environment in the IWT market lead to the establishment of the institutional transformation and ultimately to the new favorable organizational routines (e. g. (i) a regulatory system that supports the IWT market expansion; (ii) new approaches in deep-sea and inland ports governance; (iii) change in deep-sea functional focus that goes beyond the traditional port perimeter; (iv) a more open and competitive IWT market; (v) a national transport strategy that coordinates the whole national transport system of which IWT takes part etc.). Additionally, to that we extended the discussion initiated by Notteboom and 
Konings (2004) that took an evolutionary perspective to analyze the spatial dynamics and evolution of the barging network in Europe and the work of Grushevska and Notteboom (2014) by supplementing the Ukrainian Black Sea ports discussion (carried out based on economic and institutional analysis) with an evolutionary based perspective on barge-based intermodal transportation.

The answer to our central research question RQ1 "What are the critical success factors and opportunities to spur the inland navigation on Dnepr River?" will be presented below. Certainly the critical success factors determined in transport literature as crucial for any intermodal barge transport chain are valid for Ukraine as well, though there are some case specific factors and peculiarities (e.g. mind switch of the container transportation stakeholders and competitive terminal handling fees):

(i) availability of necessary infrastructure - there is a minimum available handling equipment in the main ports considered in the container network design except Kiev. This gap has to be filled with the joint efforts of national government and private forces. The other aspect of the IWW infrastructure deficiency is the river maintenance: dredging, navigation equipment such as buoys, lights, and creation of fuel bunkering facilities.

(ii) market demand characteristics - the available container demand in Ukraine (of 600k TEU per year) makes it feasible to serve a large share of it via the intermodal barge based solutions to regions such as Kherson, Dnepropetrovsk, Kiev etc. We initiated a container service that would allow about only $3 \%$ from the total container traffic (up to 20000TEU) to redirect via the river. The proposed network is just a start of barge based intermodal container transportation that can be definitely expanded to greater volumes.

(iii) services and terminals - along to the introduced network designs we underline the high importance of the service reliability and frequency of service. The same design could be delivered with a frequency minimum 3/week which still is acceptable for shippers.

(iv) backup transportation - in order to foresee the unreliability of barge transport when navigation is blocked other transport solutions should be in place such as road and rail. A practical solution for that would be the ownership of a rolling stock wagon fleet by the barge operator - up to 300 gondolas for the proposed network (and also 2-3 locomotives if the new Law on Rail comes into force) and running the container rail service only during for the 2-4 months of ice period, whereas during the summer time rent the wagons to a third party (e.g. to grain traders) and switch the container service to barges. This combination of two transport modes has several advantages: (i) no service interruption, allows the all year around 4/week container service; (ii) fill in the gaps in during the high demand peaks of the crops collection/transportation season (June-November); (iii) as well as use the time of ice period for vessel maintenance.

(v) end haul road transport - The inland container terminals which were chosen in the network are located as close as possible to the largest end consumer in order to decrease the post-haulage of containers. Ukrainian post-haulage rates (1-2 \$per TEU) are comparable and sometimes higher than the EU countries which could threaten the competitiveness of total intermodal chain costs.

(vi) the provision of an integrated end-to-end service between the deep sea terminal and the final destination - this is a highly important factor. The client served with a multimodal transport solution has to bare at least no additional costs or concerns as in comparison with unimodal (road) solution.

(vii) mind switch of the container transportation stakeholders - terminal operators, shipping companies, forwarders and end users never experienced an intermodal river based container transportation. The market acceptance of intermodal barge based container solution is very crucial success factor since Ukraine has limited experience in organizing such transport chains.

(viii) competitive terminal handling fees - in Ukrainian ports the handling fees appear to be overpriced (deep sea and inland ports) and so the total intermodal chain costs for one container from a deep sea port to an end destination consists of more than $50 \%$ of the handling costs. The port handling fees scale down tremendously the whole intermodal chain competitiveness.

The research question of this section (RQ2) was as follows: The overall chain competitiveness using Dnepr River? What are the factors and opportunities influencing the overall performance of inland transportation? In order to answer this, we based our analysis on the three concepts of the evolutionary theory applied to the IWT system in Ukraine: the organizational routine, the search and the selection environment.

Routine: The IWT system has witnessed three routine stages. The last stage is dominated by several big players that push for change: (i) terminal operators and (ii) shipping companies/own account operators. The terminal operator market is very diverse but there are several players that dominate the market such as Ukrrichflot and Nibulon, both being vertically integrated companies. As an outcome of numerous regulatory burdens (such as additional expenses on pilotage, lock usage, bridges and one-time permits) the transportation along the Dnepr becomes more expensive than multimodal or purely rail and/or road transportation. Regulatory bodies are realizing their significant outdatedness and reflect on the possible solutions for the change implementation. So the (i) external developments of the IWT market being incompatible with (ii) the current institutional arrangements trigger (iii) the institutional reflections form the 
discursive hegemony (in the third evolution stage of IWT) and push towards a search process and open the first window of opportunity. More precisely there were three active market players (Nibulon, Ukrrichflot, Hermes-trading) supported by the European business association in Ukraine (EBA) that vigorously urged as from 2008 for the needed change in the IWT institutional change. Each of the market players had their own interests but the common goal and understanding of the inefficiency in the IWT institutional and regulatory arrangements created the push to the 1st window of opportunity.

Search: Shipping companies and terminal operators perceive the problem of IWT contraction and low competitiveness. The search process of market actors forces the formation of initial ideas and solutions by the governmental bodies for a new institutional design. The last one having a relatively strongly political endorsement to revive IWT in Ukraine in the third development stage (20012-now). That led to several solutions in year 2015:

(i) implemented solutions: after three versions of IWT law one version (\#2475a) was adopted by the Transport Committee of Ukrainian Parliament (Rada) and recommended to the Rada to accept this law; documents' amount decrease to be handed to the deep sea harbor master by the inland vessel;

(ii) in progress solutions: negotiations about dredging on Bug river between Nibulon and Government of Ukraine; IWT vessel inspection optimization; regulation change in favor of reduction of inland vessel crew on board; regulation revision about compulsory pilotage on the IWT of Ukraine; regulation revision concerning bridge opening fees; regulation revision concerning increasing the towage limitation from 2 up to 4 barges simultaneously on the Dnepr-Bug Liman Canal region.

Selection environment: The general dynamics in the selection environment throughout the three routine stages identified in the IWT development can be characterized as devolution and stagnation. The unfavorable characteristics of the environment negatively affected the IWT causing its ultimate contraction. We can clearly see throughout the periods the path dependency of the IWT industry, where in each routine period it bears the seeds of its condition in the following period. This is the result of mainly the lack of an attractive regulatory and institutional framework for IWT development that triggered the lack of investments in the shipbuilding and active selling and scrapping of the fleet in the 1990s.

However, the search and selection processes in IWT's third development stage notably, simultaneously interact and provide selection feedback and at the same time influence the directions of the individual firms' search. Recent changes in the selection environment of the IWT are driven by the search processes of large vertically integrated companies which can make use of their market power and counteract the strong governmental regulatory intervention. We observe the following selection environment characteristics in the current selection environment: the market developments translated into recognized problems by all private and public stakeholders which are coming up with primary (i) solutions, (ii) institutional design and (iii) are politically supported. The early proof of the critical juncture launch and opening of the second window of opportunity is the adoption in early December 2015 of one version of the Law on IWT by the Transport Committee of Rada which is passed through to the Rada for the approval and adoption. The earlier being in fact a combination of (i) the policy solution of the institutional design and (ii) political endorsement. The determined search process has a strong potential that shapes the selection environment and the institutional transformation. The described forces threaten the long term market openness and competition level since there are few dominant players within the fleet and inland ports markets. This argument is further developed in the following part of the paper.

The initiated research demonstrated that Ukraine could play a more active role in the European cargo transportation by the use of the Dnepr and Danube Rivers. In this context Ukrainian IWT may play an essential role in logistics chains connecting the (i) Rhine-Danube and (ii) the North Sea-Baltic Sea and Baltic-Adriatic rail/road TEN-T corridors with other Sea basins and land locked regions (e.g. Baltic, Black and Mediterranean Seas, Russia and Central Asia). A potential future research avenue would be a cost and time model as well as network design for a container service between Ukrainian deep-sea ports and inland areas (inland ports and hinterland regions).

The carried out research presents some limitations due to the fact that this a case based approach and its findings are generalizable to a limited case such as inland waterways in transition economies (i.e. Russian Federation, Belarus etc.).

\section{References}

Beelen, M., 2011. Structuring and modelling decision making in the inland navigation sector. PhD Thesis, University of Antwerp, Antwerp, Belgium

Bird, J., 1980. Seaports and Seaport Terminals, Hutchinson University Library, London.

Boschma, R., Martin, R., 2010. The aims and scope of evolutionary economic geography. The handbook of evolutionary economic geography, 3-39.

Boschma, R.A., Frenken, K., 2006. Why is economic geography not an evolutionary science? Towards an evolutionary economic geography. Journal of economic geography 6, 273-302.

Boschma, R.A., Lambooy, J.G., 1999. Evolutionary economics and economic geography. Journal of evolutionary economics 9 , 
411-429.

Buitelaar, E., Lagendijk, A., Jacobs, W., 2007. A theory of institutional change: illustrated by Dutch city-provinces and Dutch land policy. Environment and Planning A 39, 891-908.

Choi, J.H., Barnett, G.A., CHON, B.S., 2006. Comparing world city networks: a network analysis of Internet backbone and air transport intercity linkages. Global Networks 6, 81-99.

Derudder, B., Witlox, F., 2009. The impact of progressive liberalization on the spatiality of airline networks: a measurement framework based on the assessment of hierarchical differentiation. Journal of Transport Geography 17, 276-284.

Doubrovsky, M., 2005. Ukrainian and Russian waterways and the development of European transport corridors. European Transport 30, 14-36.

Egis International, Dornier Consulting, 2013. Logistics Processes and Motorways of the Sea II. LOGMOS Master Plan - Annex 6, Part I, TRACECA Inland Waterways - Dnepr Case Study.

Frémont, A., Franc, P., Slack, B., 2009. Inland barge services and container transport: the case of the ports of Le Havre and Marseille in the European context. Cybergeo: European Journal of Geography, 〈http://cybergeo.revues.org/21743>.

Fujita, M., Mori, T., 1996. The role of ports in the making of major cities: self-agglomeration and hub-effect. Journal of development Economics 49, 93-120.

Fujita, M., Mori, T., 1997. Structural stability and evolution of urban systems. Regional science and urban economics 27, $399-442$.

Fujita, M., Krugman, P., Mori, T., 1999. On the evolution of hierarchical urban systems. European Economic Review 43, $209-251$.

Grushevska, K., Moskvichenko, I., 2013. Konkurencja o rosyjski i wschodnioeuropejski rynek między portami wschodniego wybrzeża Bałtyku. Współczesna Gospodarka 4, 25-44.

Grushevska, K., Notteboom, T., Shkliar, A., 2016. Institutional rail reform: The case of Ukrainian Railways. Transport Policy 46, 7-19.

Grushevska, K., Notteboom, T., 2014. An Economic and Institutional Analysis of Multi-Port Gateway Regions in the Black Sea Basin. Journal of International Logistics and Trade 12, 3-35.

Grushevska, K., Notteboom, T., 2015. From centrality to intermediacy in the global transport network? Ukraine's trials and tribulations as a potential transit country. Proceedings of the International Association of Maritime Economists Conference, Kuala Lumpur, Malaysia.

Grushevska, K., Notteboom, T., Shkliar, A., 2014. Ukrainian railways - the need for institutional change. Vervoerslogistieke werkdagen, Breda.

Guimerà, R., Amaral, L.A.N., 2005. Functional cartography of complex metabolic networks. Nature 433, 895-900.

Gunthner Ginkels, 2015. Inland waterways. Proceedings of the Maritime Days Conference, Odessa, Ukraine.

Jacobs, W., Notteboom, T., 2011. An evolutionary perspective on regional port systems: the role of windows of opportunity in shaping seaport competition. Environment and Planning A 43, 1674-1692.

Kingdon, J.W., 1995. The policy window, and joining the streams. Agendas, alternatives, and public policies, 172-189.

Konings, J.W., 2008. The future of intermodal freight transport: operations, design and policy. Edward Elgar Publishing.

Konings, J.W., 2009. Intermodal barge transport: network design, nodes and competitiveness. TU Delft, Delft.

Kreutzberger, E., Konings, R., Aronson, L., 2006. Evaluation of pre-and post-haulage in intermodal freight networks. Towards better performing transport networks, 256-284.

Kreutzberger, E.D., 2008. The Innovation of Intermodal Rail Freight Bundling Networks in Europe Concepts, Developments, Performances. TRAIL Thesis Series nr. T2008/16, Delft, Netherlands

Lee, S.W., Song, D.W., Ducruet, C., 2008. A tale of Asia's world ports: the spatial evolution in global hub port cities. Geoforum 39, 372-385.

Macharis, C., 2000. Hybrid Modeling: System Dynamics combined with Multi-criteria Analysis. Proceedings of an Application to Intermodal Transport, System Dynamics Conference, Bergen, Norway.

MacKinnon, D., Cumbers, A., Pike, A., Birch, K., McMaster, R., 2009. Evolution in economic geography: institutions, political economy, and adaptation. Economic geography 85, 129-150.

Martin, R., Sunley, P., 2007. Complexity thinking and evolutionary economic geography. Journal of Economic Geography, 1-29.

Nelson, R.R., 2002. Bringing institutions into evolutionary growth theory. Journal of Evolutionary Economics 12, 17-28.

Nguyen, C.L., Notteboom, T., 2016. Dry Ports As Extensions of Maritime Deep-Sea Ports: a Case Study of Vietnam. Journal of International Logistics and Trade 14, 65-88.

Notteboom, T., 2007. Container river services and gateway ports: similarities between the Yangtze River and the Rhine River. Asia Pacific Viewpoint 48, 330-343.

Notteboom, T., Konings, R., 2004. Network dynamics in container transport by barge. Belgeo. Revue belge de géographie 4, 461-478.

Notteboom, T.E., 2004. A carrier's perspective on container network configuration at sea and on land. Journal of International Logistics and Trade 1, 65-87.

Notteboom, T.E., Rodrigue, J.P., 2005. Port regionalization: towards a new phase in port development. Maritime Policy \& Management 32, 297-313.

Panayides, P.M., 2002. Economic organization of intermodal transport. Transport Reviews 22, 401-414.

Pelikan, P., 2003. Bringing institutions into evolutionary economics: another view with links to changes in physical and social technologies. Journal of Evolutionary Economics 13, 237-258.

Platz, T.E. 2009. The Efficient Integration of Inland Shipping into Continental Intermodal Transport Chains - Measures and Decisive Factors. TRAIL Thesis Series nr. T2009/7, the Netherlands TRAIL Research School, 329.

Rigby, D.L., Essletzbichler, J., 1997. Evolution, process variety, and regional trajectories of technological change in US manufacturing. Economic Geography 73, 269-284.

Robinson, R., 2002. Ports as elements in value-driven chain systems: the new paradigm. Maritime Policy \& Management 29 , 241-255.

Rodrigue, J.P., 2008. The Thruport concept and transmodal rail freight distribution in North America. Journal of Transport 
The Development of River-based Intermodal Transport: The Case of Ukraine

Geography 16, 233-246.

Shkliar, A., 2015. Inland waterways: Role and means of river transportation in Europe. Maritime days, Odessa.

Taaffe, E.J., Morrill, R.L., Gould, P.R., 1963, Transport expansion in underdeveloped countries: a comparative analysis. Geographical Review 53, 503-529.

Ukrrichflot Official website. <http://ukrrichflot.ua/en/>

Van Der Horst, M.R., De Langen, P.W., 2008. Coordination in hinterland transport chains: a major challenge for the seaport community. Maritime Economics \& Logistics 10, 108-129.

Van Klink, H.A., 1998. The port network as a new stage in port development: the case of Rotterdam. Environment and Planning A $30,143-160$.

Veenstra, A., Notteboom, T., 2011. The development of the Yangtze River container port system. Journal of Transport Geography 19, 772-781.

Winter, S.G., Nelson, R.R., 1982. An Evolutionary Theory of Economic Change. University of Illinois at Urbana-Champaign Press, Illinois. 